Ind. Health, 1970, 8, 31.

\title{
STUDIES ON POISONING BY BENZENE AND ITS HOMOLOGUES
}

\section{(12) STRAIN DIFFERENCE IN SUSCEPTIBILITY TO BENZENE IN RAT, AND STANDARDIZATION OF BENZENE POISONING EXPERIMENT}

\author{
Kazuo NOMIYAMA* and Masao MINAI \\ Department of Hygiene, Tokyo Medical and Dental University \\ School of Medicine, Bunkyo-ku, Tokyo 113
}

(Received June 23, 1970)

\begin{abstract}
Donryu, Wistar and Sprague-Dawley strains of rat were studied on their responses to the subcutaneously administered benzene at dose levels of $0,0.2,0.5$ and $1.0 \mathrm{ml} /$ $\mathrm{kg} /$ day for 5 days. Criteria were body weight, hemoglobin, eryth rocyte, leucocyte, thrombocyte, thymus weight, and spleen weight.

Among 3 strains of rat, Sprugue-Dawley was found most sensitive to benzene and to respond at a $0.5 \mathrm{ml} / \mathrm{kg}$ dose level. Female showed higher susceptibility to benzene than male. Useful criteria for benzene intoxication in rat might be the decrease of body weight, leucocyte count, thymus weight and spleen weight, and the increase of thrombocyte count. The Sprague-Dawley rat is found to be the best animal strain in the benzene intoxication experiment because of having many critical organs, the highest suseptibility to benzene, and the smallest variation of the measurement.

And the standardization of benzene poisoning experiment was shown from the viewpoint of animal species, dose and critical organs in relation to minimum effective dose.
\end{abstract}

Industrial toxicology experiments have been performed by the use of various kinds of animals, environment of the cage, dose, duration and way of the exposure, and criterion. And the results were quite different and independent each other, and were, unfortunately, incomparable because of their different exparimental materials and methods.

The present authors have intended to standardize the experimental factors in benzene poisoning. In this series of experiments, ${ }^{1-4)}$ experimental animals were fed with commercial pelleted food and water ad libitum in the cages of $21 \pm 2^{\circ} \mathrm{C}$ temperature and $55 \pm 5 \%$ relative humidity. Animals were given benzene in olive

Read before the 66 th Meeting of Kanto Branch of Japan Associon of Industrial Health, Tokyo, April 17, 1965.

* Present address : Department of Hygiene, Gunma University School of Medicine, Showamachi, Maebashi 371. 


\section{K. NOMIYAMA AND M. MINAI}

oil in daily subcutaneous injections on the back for 5 days, and on the 6 th day of the experiment the benzene intoxication was evaluated with criteria of appearance, body weight, hemoglobin content, erythrocyte count, thrombocyte count, thymus weight and spleen weight. Data were processed in three ways : analysis of variance (multiple-way layout), changes in the measurement by benzene administration (Tukey's test), and coefficients of variance of the measurement ${ }^{5)}$. And it was discussed the response of animals to benzene as well as the selection of experimental animals in benzene poisoning.

The rat was found to be the best animal species among 4 (rabbit, hamster, rat and mouse) in benzene poisoning ${ }^{3)}$.

And the present authors attempted to find the best strain of rat in benzene intoxication experiment.

\section{Materials AND Methods}

Three strains of rat were used in the present experiment: Donryu, Wistar and Sprague-Dawley, which were purchased from Japan CLEA, Ltd., and bred later conventionally at our laboratory. Animals used were 24 rats of both sexes of one strain, in all 72 rats. The experiment started with 4 groups of 8 weeks by giving them benzene subcutaneously on the back at various dose levels of $0,0.2$, 0.5 and $1.0 \mathrm{ml} / \mathrm{kg} /$ day for 5 days. On the 6 th day of the experiment changes of body weight and hemopoiesis were examined to evaluate the benzene intoxication. Criteria and data processings were the same as that in the previous paper").

\section{RESUlts}

\section{Body Weight}

Table 1. Strain difference in susceptibility to benzene in rat.

\begin{tabular}{|c|c|c|c|c|c|c|}
\hline & \multicolumn{2}{|c|}{ Donryu } & \multicolumn{2}{|c|}{ Wistar } & \multicolumn{2}{|c|}{ Sprague-Dawley } \\
\hline & $\hat{o}$ & 우 & $\hat{o}$ & 우 & $\hat{\delta}$ & ㅇ \\
\hline Body Weight & - & $\downarrow 1.0$ & $\downarrow 1.0$ & - & $\downarrow 1.0$ & - \\
\hline Hemoglobin & $\uparrow 1.0$ & - & - & - & - & - \\
\hline Erythrocyte & - & - & 一 & - & - & - \\
\hline Leucocyte & $\downarrow 1.0$ & - & $\downarrow 1.0$ & - & $\begin{array}{l}10.5 \dagger \\
\downarrow 1.0 \dagger\end{array}$ & $\begin{array}{l}0.2 \dagger \\
0.5 \dagger \\
\downarrow 1.0 \dagger\end{array}$ \\
\hline Thrombocyte & $\uparrow 1.0$ & $\uparrow 1.0$ & $\uparrow 1.0 \dagger$ & $\begin{array}{l}\uparrow 0.5 \dagger \\
1.0 \dagger\end{array}$ & $\uparrow 1$. o† & $\uparrow \begin{array}{l}0.5 \\
1.0\end{array}$ \\
\hline Thymus & $\begin{array}{l}0.2 \\
0.5 \dagger \\
1.0 \dagger\end{array}$ & $\downarrow 0.5$ & - & - & $\downarrow 1.0$ & $\downarrow 1.0$ \\
\hline Spleen & $\begin{array}{l}10.5 \\
\downarrow 1.0\end{array}$ & $\downarrow 1.0$ & - & - & $\begin{array}{l}\text { l0.5† } \\
\downarrow 1.0 \dagger\end{array}$ & $\mid \begin{array}{l}0.2 \\
0.5 \dagger \\
1.0 \dagger\end{array}$ \\
\hline
\end{tabular}

Changes are significant at $5 \%$ level ( $\dagger 1 \%$ level), when benzene was given at a dose of figure $(\mathrm{ml} / \mathrm{kg})$. Vacant fields indicate no remarkable changes. Upward arrows show the increase, and downward arrows the dearease, respectively. 


\section{BENZENE POISONING}

Body weight decreased by benzene administration. The more benzene was given, the more body weight was lost. There was no sexual difference in weight loss due to benzene.

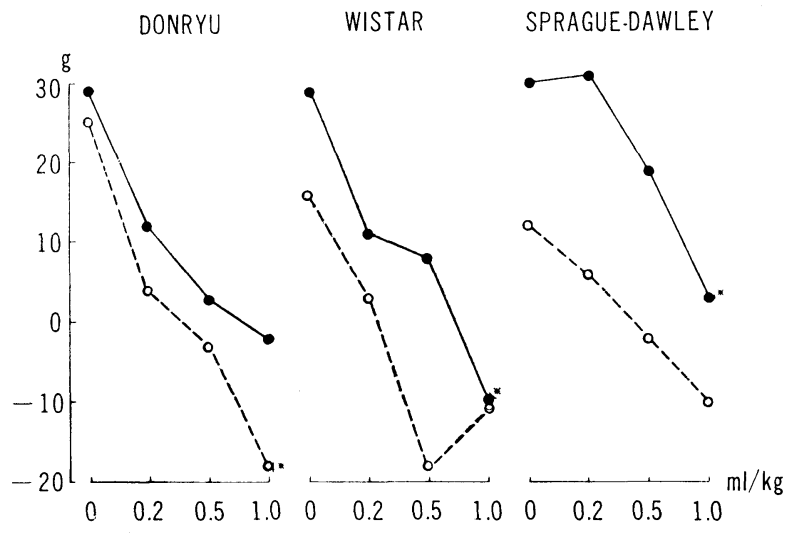

Fig. 1. Body weight.

The difference of body weight between before and after the benzene administration $(0,0.2,0.5$ or $1.0 \mathrm{ml} / \mathrm{kg}$ for five days) was shown. Solid line and dashed line indicate male and female, respectively. Marks* and** show the remarkable difference between the control group and the concerned group at $5 \%$ and $1 \%$ level of significance.

\section{Hemoglobin}

Benzene-treated animals were more hyperchromic than control animals.

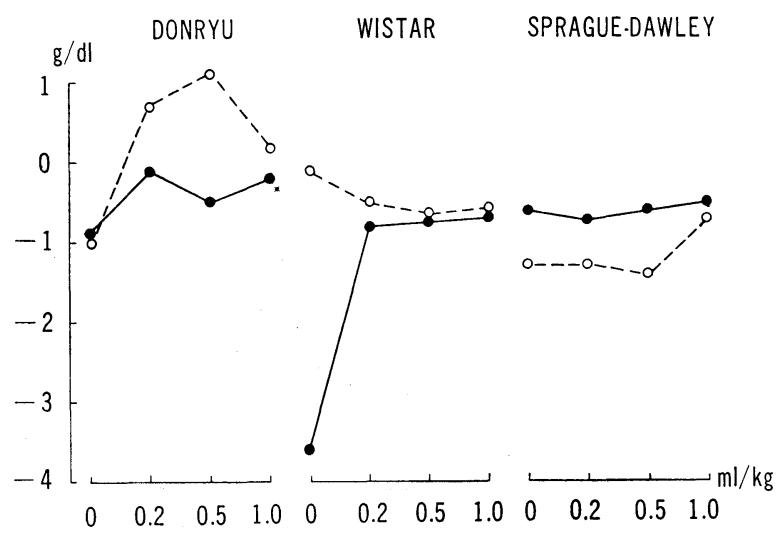

Fig. 2. Hemoglobin content.

Donryu strain was rather more hyperchromic than Wistar and Sperague-Dawley strains.

\section{Erythrocyte}

Significant changes could not be detected in erythrocyte count due to benzene administration, sex, and strain.

\section{Leucocyte}

Benzene decreased leucocyte count remarkably in proportion to the dose of ben- 
K. NOMIYAMA AND M. MINAI

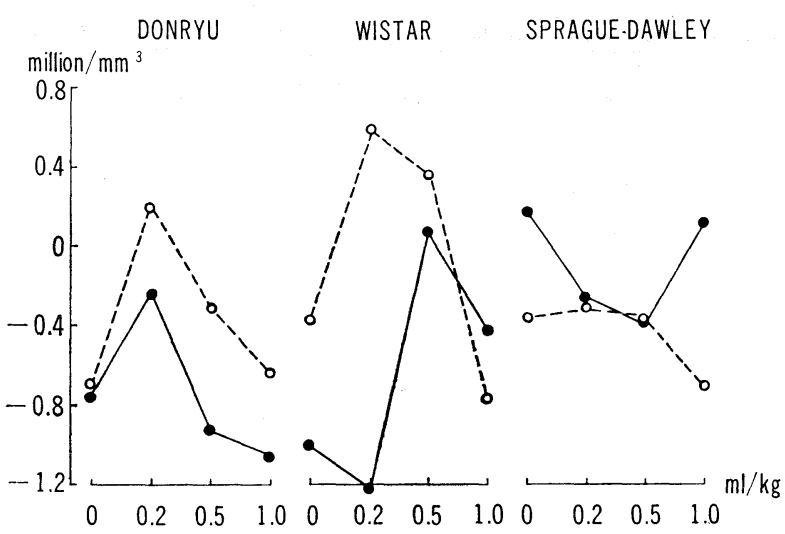

Fig. 3. Erythrocyte count.

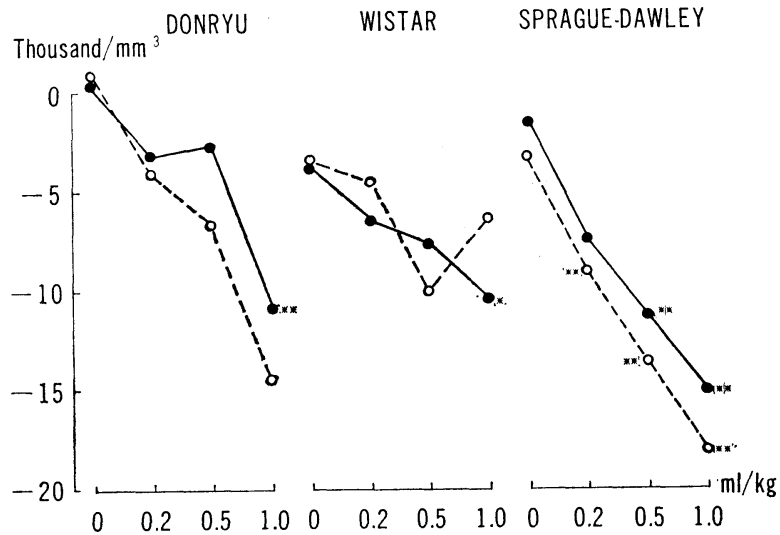

Fig. 4. Leucocyte count.

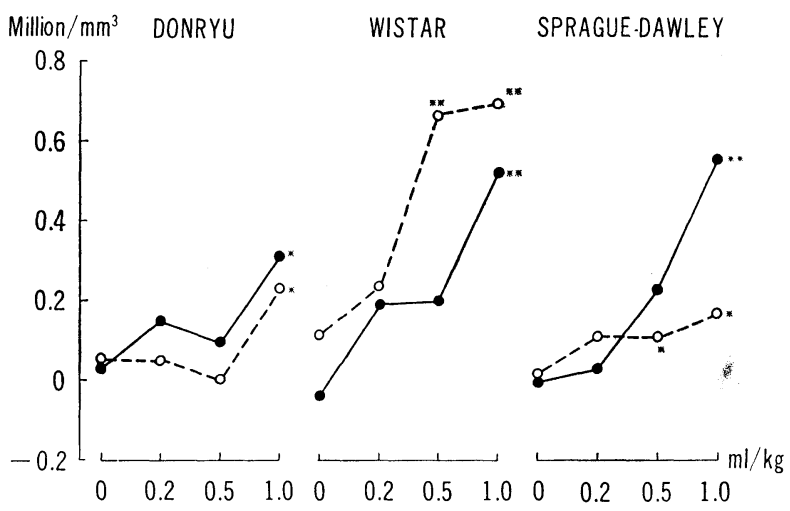

Fig. 5. Thrombocyte count.

zene. Female Sprague-Dawley showed profound leucopenia in response to the least amount of benzene $(0.2 \mathrm{ml} / \mathrm{kg} /$ day $)$.

The decrease of leucocyte count in Sprague-Dawley was larger than other 2 strains in 6 days of the experiment. 


\section{BENZENE POISONING}

\section{Thrombocyte}

Thrombocytosis was observed in benzen-treated animals. The greater increase of thrombocyte count was observed when the larger amount of benzene was given to the animals.

The thrombocytosis was remarkable in Wistar strain especially in female Wistar rats.

Thymus weight

Thymus lost its weight by benzene administration proportionally to the dose. Greater decrease was observed in male as well as in Donryu strain.

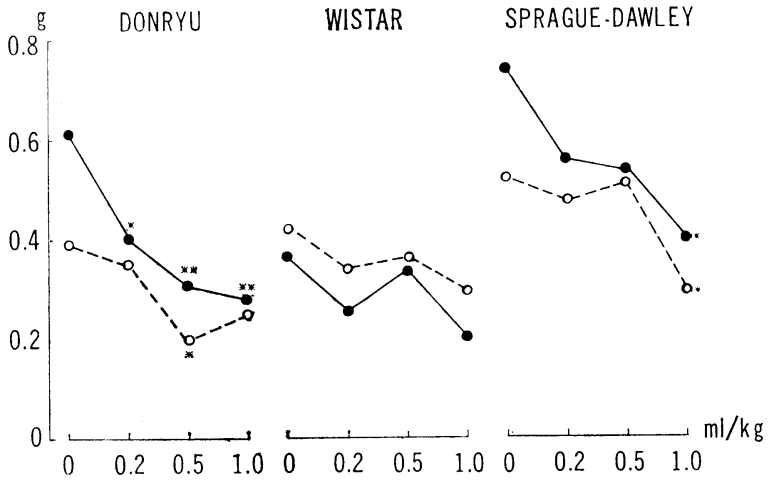

Fig. 6. Thymus weight.

Thymus weight at the end of the experiment was shown.

Thymus weight was greater in male, and so was in Sprague-Dawley strain.

Spleen weight

Benzene decreased spleen weight in proportion to the dose of benzene. SpragueDawley seemed most sensitive to benzene in the index of spleen weight.

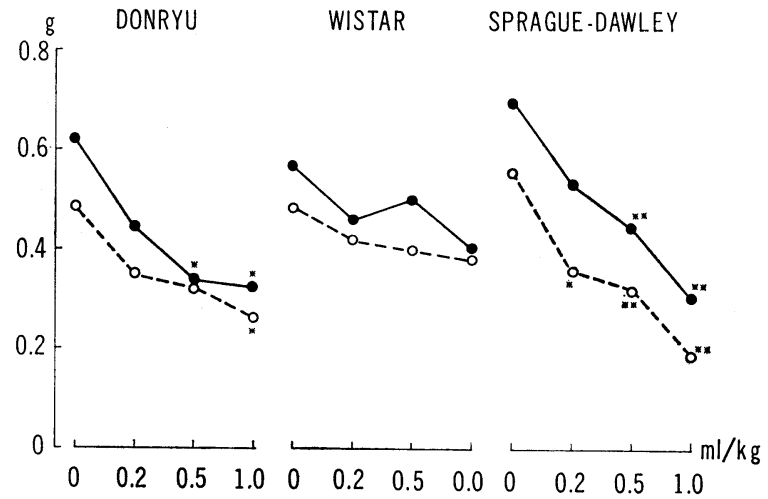

Fig. 7. Spleen weight.

There could not be found obvious strain difference in spleen weight. 


\section{K. NOMIYAMA AND M. MINAI}

\section{Discussion}

Standardization of experimental factors in benzene poisoning have been tried through a series of papers by the present authors. ${ }^{1 \sim 4)}$

The experimental animals were fed with commercial pelleted food and water ab libitum throughout all the experiment.

Environmental temperature was examined upon its effect on the susceptibility to benzene ${ }^{1)}$. Rats, bred at $21^{\circ} \mathrm{C}$, were acclimatized to $32^{\circ} \mathrm{C}, 21^{\circ} \mathrm{C}$ and $10^{\circ} \mathrm{C}$ (relative humidity 55\%) for 8 days. The rats were then administered benzene subcutaneously for 12 days. Considerable leucopenia was found at $32^{\circ} \mathrm{C}$ and $21^{\circ} \mathrm{C}$, while no changes of leucocyte count were observed at $10^{\circ} \mathrm{C}$. And thereafter all experiments were performed at $21 \pm 2^{\circ} \mathrm{C}$ and $55 \pm 5 \%$ relative humidity.

Four species of animal (rabbit, hamster, rat and mouse) were tested on the susceptibility to benzene ${ }^{3)}$. Young adults were employed in the experiment, because there was observed the age difference in the susceptibility as indicated below. Rat was found the most sensitive and hamster was resistant to benzene among 4 species. Female animals showed higher susceptibility than male in rabbit and rat, but lower susceptibility in mouse and hamster. Critical organs in benzene intoxication were leucocyte count, thymus weight and spleen weight, but were a little different among 4 species-hemoglobin in rabbit, hemoglobin and thrombocyte count in hamster, body weight in rat, and erythrocyte count in mouse. Response to benzene and coefficient of variance before and after the treatment indicated that rat was the best animal species in the benzene intoxication experiment.

The effect of age factor on the sensitivity was studied ${ }^{2}$, and young rats were found to have higher susceptibility to benzene than mature ones. Mice, on the other hand, showed no significant difference between young and mature animals.

As to strain difference, 5 strains of mouse (ICR, ddN, CF \# $1, \mathrm{CFW}$ and $\mathrm{C}_{3} \mathrm{H}$ ) were examined on the susceptibility to benzenet) and $d d N$ was found the most susceptible and ICR was the least susceptiale to benzene. ICR and $\operatorname{ddN}$ were thought good strains in the benzene poisoning experiment because of the small coefficient of variance among 5 strains of mouse.

The present experiment was focused to find the best animal, that is, the best strain of rat in the benzene poisoning experiment.

Although mice have been reported occasionally on the strain difference in susceptibility to chemicals ${ }^{6-10)}$ have been hardly reported, to the authors' knowledge, on the strain difference in sensitivity to the poisoning so far.

Among 3 strains of rat (Donryu, Wistar and Sprague-Dawley), Sprague-Dawley was found the most susceptible to benzene to show the greater changes in many criteria at a smaller dose of benzene. In consideration of the smallest variation of measurements ${ }^{5}$. Sprague-Dawley might be the best animal in the benzene poisoning experiment. This strain of rat originally came from Charles River Breeding Laboratory in the United States, and has been bred primarily as a specific 


\section{BENZENE POISONING}

Table 2. Coefficient of variance in rat.

\begin{tabular}{|c|c|c|c|c|c|c|}
\hline & \multicolumn{2}{|c|}{ Donryu } & \multicolumn{2}{|c|}{ Wistar } & \multicolumn{2}{|c|}{ Sprague-Dawley } \\
\hline & 임 & ㅇ & $\hat{o}$ & ㅇ & $\hat{\delta}$ & 우 \\
\hline Body weight & $\begin{array}{l}7.5 \% \\
11.7\end{array}$ & $\begin{array}{l}4.9 \% \\
10.1\end{array}$ & $\begin{array}{l}4.3 \% \\
7.5\end{array}$ & $\begin{array}{l}4.5 \% \\
9.0\end{array}$ & $\begin{array}{l}4.4 \% \\
3.9\end{array}$ & $\begin{array}{l}7.2 \% \\
8.5\end{array}$ \\
\hline Hemoglobin & $\begin{array}{r}11.9 \\
9.5\end{array}$ & $\begin{array}{l}10.2 \\
11.0\end{array}$ & $\begin{array}{l}9.8 \\
7.2\end{array}$ & $\begin{array}{l}9.7 \\
8.1\end{array}$ & $\begin{array}{l}4.4 \\
5.2\end{array}$ & $\begin{array}{l}3.9 \\
9.5\end{array}$ \\
\hline Erythocyte & $\begin{array}{r}12.5 \\
8.2\end{array}$ & $\begin{array}{r}6.5 \\
17.2\end{array}$ & $\begin{array}{r}6.5 \\
10.0\end{array}$ & $\begin{array}{r}9.8 \\
10.0\end{array}$ & $\begin{array}{l}5.1 \\
6.6\end{array}$ & $\begin{array}{l}6.9 \\
5.2\end{array}$ \\
\hline Leucocyte & $\begin{array}{l}14.0 \\
28.1\end{array}$ & $\begin{array}{l}51.2 \\
41.6\end{array}$ & $\begin{array}{l}13.2 \\
17.0\end{array}$ & $\begin{array}{l}43.0 \\
37.1\end{array}$ & $\begin{array}{r}9.4 \\
13.5\end{array}$ & $\begin{array}{l}25.3 \\
27.4\end{array}$ \\
\hline Thrombocyte & $\begin{array}{l}11.8 \\
12.3\end{array}$ & $\begin{array}{l}12.6 \\
17.8\end{array}$ & $\begin{array}{l}12.6 \\
16.3\end{array}$ & $\begin{array}{l}12.4 \\
19.2\end{array}$ & $\begin{array}{l}11.4 \\
19.8\end{array}$ & $\begin{array}{r}7.5 \\
11.6\end{array}$ \\
\hline Thymus & $\begin{array}{l}34.0 \\
20.6\end{array}$ & $\begin{array}{l}32.2 \\
22.3\end{array}$ & $\begin{array}{l}32.2 \\
28.6\end{array}$ & $\begin{array}{l}28.3 \\
30.7\end{array}$ & $\begin{array}{l}30.1 \\
25.8\end{array}$ & $\begin{array}{l}26.4 \\
19.7\end{array}$ \\
\hline Spleen & $\begin{array}{l}33.2 \\
24.7\end{array}$ & $\begin{array}{l}32.0 \\
25.9\end{array}$ & $\begin{array}{l}22.2 \\
20.8\end{array}$ & $\begin{array}{l}20.8 \\
23.3\end{array}$ & $\begin{array}{l}31.7 \\
19.2\end{array}$ & $\begin{array}{l}40.4 \\
19.5\end{array}$ \\
\hline
\end{tabular}

Upper column of each field shows a coefficient of variance before the treatment, and lower column shows a coefficient after the treatment. Vacant fields indicate no data obtained.

pathogen-free animal at Japan CLEA laboratory. Our experiments, however, performed under a conventional environment. Donryu rat are now widely used in the field of cancer research. Although it responded to benzene in most criteria, the variation of the measurements was rather large and it does not seem a good animal in the benzene intoxication research. Wistar strain, which has been generally used in most benzene poisoning experiment, showed small changes in a few criteria. It seems now to lose its uniformity and to show different responses to the stimulus among substrains. And the present authors can not agree to recommend to use Wistar strain in future benzene intoxication experiments.

Mechanism of difference in susceptibility to benzene among 3 strains of rat is not clear yet, but might be very similar to the mechanism of age and sexual difference in susceptibility; differences in benzene oxidation ${ }^{11,12)}$ and in sulfate conjugation of benzene metabolites ${ }^{13)}$ and in sensitivity of hemopoietic tissue to benzene metabolites.

\section{Conclusion}

It was attempted to standardize the experimental factors in benzene poisoning.

1. Sprague-Dawley rat of young adult was found the best animal in the benzene intoxication experiment, when they were fed with commercial pelleted food and water ad libitum in cages of $21^{\circ} \mathrm{C}$ temperature and $55 \%$ relative humidity and when they were given the subcutaneous injection of benzene at dose of over 0.5 


\section{K. NOMIYAMA AND M. MINAI}

$\mathrm{ml} / \mathrm{kg}$ on the back for 5 days. Critical organs were body weight, leucocyte count, thrombocyte count, thymus weight, and spleen weight.

2. Minimun effective doses and critical organs in 4 species of animal were summarized in Table 3, which might enable us to compare various data so far reported and to choose animal species, dose, and criteria effectively in future experiments.

Table 3. Minimum effective dose and critical organs in benzene poisoning.

\begin{tabular}{|c|c|c|c|c|c|c|c|c|c|c|c|}
\hline Species and age & & \begin{tabular}{|c} 
Rabbit \\
$(2.5-$ \\
$3.0(\mathrm{~kg})$
\end{tabular} & $\begin{array}{c}\text { Hamster } \\
\text { (2 months) }\end{array}$ & & $\begin{array}{l}\text { Rat } \\
\text { (8 weeks) }\end{array}$ & & \multicolumn{5}{|c|}{$\begin{array}{c}\text { Mouse } \\
\text { (5 weeks) }\end{array}$} \\
\hline Strain & & Japanese & $\begin{array}{l}\text { Golden } \\
\text { hamster }\end{array}$ & Donryu & Wistar & $\begin{array}{l}\text { Sprague } \\
\text { Dawley }\end{array}$ & ICR & $\mathrm{CF} \#$ & $1 \mathrm{ddN}$ & NCF & $\mathrm{W} \mathrm{C}_{3} \mathrm{H}$ \\
\hline $\begin{array}{l}\text { Minimum effective } \\
\text { dose (ml/kg, subcu- } \\
\text { taneous for } 5 \text { days) }\end{array}$ & $\begin{array}{l}\hat{0} \\
\stackrel{+}{+}\end{array}$ & $\begin{array}{l}0.5 \\
0.5\end{array}$ & $\begin{array}{l}0.5 \\
1.0\end{array}$ & $\begin{array}{l}0.2 \\
0.5\end{array}$ & $\begin{array}{l}1.0 \\
0.5\end{array}$ & $\begin{array}{l}0.5 \\
0.2\end{array}$ & $\begin{array}{l}0.5 \\
0.5\end{array}$ & $\begin{array}{l}0.2 \\
1.0\end{array}$ & $\begin{array}{l}0.2 \\
0.5\end{array}$ & $\begin{array}{l}0.2 \\
1.0\end{array}$ & $\begin{array}{l}1.0 \\
1.0\end{array}$ \\
\hline Body weight & & & & 0 & 0 & 0 & & & & & \\
\hline $\begin{array}{l}\text { Hemoglobin content } \\
\text { Erythrocyte count }\end{array}$ & & $\bigcirc$ & $\bigcirc$ & O & & & & & 0 & & \\
\hline Leucocyte count & & 0 & & 0 & 0 & 0 & 0 & 0 & 0 & & 0 \\
\hline Thrombocyte count & & & O & 0 & 0 & 0 & & & & & \\
\hline Thymus weight & & O & O & $\bigcirc$ & & $\bigcirc$ & & & $\bigcirc$ & $\mathrm{O}$ & 0 \\
\hline Spleen weight & & O & & 0 & & O & O & $\bigcirc$ & 0 & $\bigcirc$ & $\bigcirc$ \\
\hline
\end{tabular}

\section{Acknowledgement}

The authors should like to express their thanks to Professor H. Kita for his continued interest in this study.

\section{REFERENCES}

1) Nomiyama, K. (1965). Ind. Health (Kawasaki), 3, 58.

2) Nomiyama, K., Minai, M. and Kita, H. (1965). Ind. Health (Kawasaki), 3, 91.

3) Minai, M. (1967). Bull. Tokyo Med. Dent. Univ., 14, 327.

4) Nomiyama, K. and Minai, M. (1969). Ind. Health (Kawasaki), 7, 54.

5) Nomiyama, K. (1966). Bull. Exptl. Animals (Tokyo), 15, 10. (in Japanese with English Abstract).

6) Ikeda, Y. (1958). Mombusho Sogokenkyuhokoku Shuroku (Med. Pharm.) (1957), 176, Nihon-Gakujutsu-Shinkokai, Tokyo, (in Japanese).

7) Masuda, Y., Watanabe, M. and Takahashi, H. (1963). Japan. J. Hyg., 18, 345. (in Japanese with English Abstract).

8) Harashima, S. (1958). Mombusho Sogokenkyuhokoku Shuroku (Med. Pharm.) (1957), 176. Nihon-Gakujutsu-Shinkokai, Tokyo, (in Japansse).

9) Harashima, S. (1961). Bull. Exptl. Animals (Tokyo), 10, 31, (in Japanese).

10) Harashima, S., Sakurai, H. and Nakamura, K. (1965). Japan. J. Ind. Health, 7, 676. (in Japanese with English Abstract).

11) Nomiyama, K. (1962) Med. J. Shinshu Univ., 7, 41.

12) Nomiyama, K. (1965). Ind. Health (Kawasaki), 3, 53.

13) Ikeda, M. (1964). J. Biochem. (Tokyo), 55, 231. 